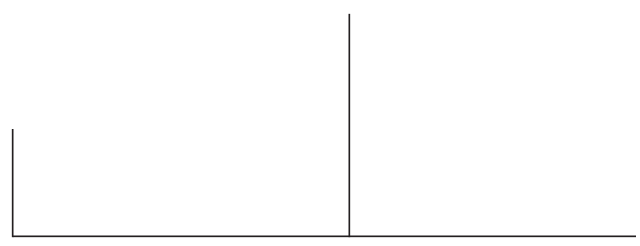

\title{
Uma reflexão sobre a psicose na teoria freudiana
}

\author{
Joyce M. Gonçalves Freire
}

\begin{abstract}
O objetivo deste artigo é trilhar o movimento do pensamento freudiano em relação à psicose. A princípio, o tema da psicose - em especial a paranóia - é desenvolvido por Freud no interior de sua concepção sobre as neuroses, portanto, no terreno da repressão (Verdrängung) para, posteriormente, encontrar sua especificidade conceitual na rejeição (Verwerfund) e na recusa (Verleugnung), conceitos estes tributários das especulações freudianas sobre o narcisismo e a elaboração da, assim chamada, segunda tópica. É também discutida a questão da dificuldade da clínica freudiana para as psicoses pela impossibilidade da transferência.
\end{abstract}




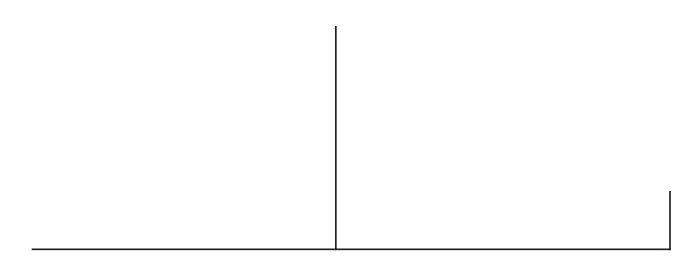

Sabemos que a clínica freudiana está fundada na questão histérica. Freud, fundamentado na questão prática da relação transferencial, pensava ser difícil, senão impossível, o atendimento psicanalítico com psicóticos. De um ponto de vista teórico, veremos que a teoria freudiana dá respostas ao enigma da psicose; porém, no que diz respeito ao atendimento clínico, Freud pouco nos diz sobre ela.

No entanto, se o grande interesse freudiano voltava-se para a bela histérica, Freud não deixará de deitar seu olhar investigativo na questão da psicose. Diversamente de seus contemporâneos suíços que se voltaram para a pesquisa da esquizofrenia, Freud volta sua curiosidade analítica para a paranóia. A esse respeito, Lacan nos fala em seu seminário dedicado às psicoses:

Naturalmente, Freud não ignorava a esquizofrenia. O movimento de elaboração desse conceito era-lhe contemporâneo. Mas se certamente reconheceu, admirou e mesmo encorajou os trabalhos da escola de Zurique, e pôs a teoria analítica em relação com o que se edificava em torno de Bleuler, ele, no entanto, se manteve suficientemente afastado. Ele se interessou primeiro e essencialmente pela paranóia. E para indicar-lhes imediatamente um ponto de referência ao qual vocês poderão se reportar, lembro-lhes que no fim da observação do 


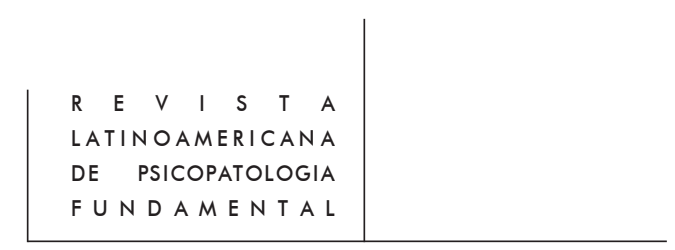

caso Schreber, que é o texto de maior doutrina concernente às psicoses, Freud traça uma linha divisora de águas, se assim posso me exprimir, entre paranóia, de um lado, e, de outro, tudo o que gostaria, diz ele, que fosse chamado de parafrenia, e que corresponde exatamente às esquizofrenias. ${ }^{1}$

De um ponto de vista histórico, nas cartas a Fliess, Freud já tentava dar um explicação para o fenômeno da paranóia. Em sua carta de 24 de janeiro de $1895^{2}$ vemos que já considerava a paranóia uma neurose de defesa, cujo mecanismo principal é a projeção. Esta noção de defesa aplicada à paranóia acompanhará Freud, como veremos, em seus escritos posteriores (Caso Schreber). Em uma carta datada de 09 de dezembro de $1899^{3}$, percebemos algo novo em sua tentativa de entender a paranóia, na qual considerava que a mesma era acarretada pelo retorno a um auto-erotismo primitivo.

Em 1910, Freud escreve um artigo no qual faz uma leitura psicanalítica dos escritos do Presidente Schreber ${ }^{4}$, paranóico brilhante que, antes de morrer escreve e edita suas memórias (Memórias de um doente de nervos). Não vamos detalhar aqui o caso Schreber, mas apenas traçar algumas linhas para a compreensão do mesmo, compilar as principais idéias freudianas no que diz respeito à paranóia $\mathrm{e}$ delimitar quais avanços teóricos foram feitos desde suas elaborações nas cartas a Fliess.

Schreber teve três crises que o levaram a internações. Seus sintomas, que não eram poucos, devem ser compreendidos no interior de sua estrutura psicótica. Era hipocondríaco e sua hipocondria estava inserida no todo de sua transformação corporal, a transformação do corpo-próprio, tão fundamental na construção de seus delírios. Acreditava estar morto e em decomposição. É importante notar que Freud estabelece uma estreita relação entre a paranóia e a hipocondria e vem a dizer que a angústia está para a histeria de angústia, assim como a hipocondria está para a paranóia. ${ }^{5}$

Schreber teve num determinado dia, no intervalo entre o sono e a vigília, o seguinte pensamento: "deve ser bom ser mulher e submeter-se ao ato da cópula", e veremos que esta fantasia desejante norteará seu delírio.

1. J. Lacan. O seminário. As psicoses. Livro 3. Rio de Janeiro, Jorge Zahar, 1985, p. 12.

2. Jeffrey Moussaief Masson (ed.). A correspondência completa de Sigmund Freud para Wilhelm Fliess - 1887-1904. Trad. de Vera Ribeiro. Rio de Janeiro, Imago, 1986.

3. Idem.

4. S. Freud. "Notas psicanalíticas sobre um relato autobiográfico de um caso de paranóia" (1911). E.S.B. Rio de Janeiro, Imago, 1974.

5. Idem, p. 77.

6. Idem, p. 28. 


\section{ARTIGOS}

Seu primeiro médico teve uma importância especial na construção de sua paranóia. Flechsig, a quem dedicara uma profunda admiração, torna-se seu perseguidor e vem a ser o "assassino de almas". Posteriormente, seu delírio de perseguição toma, gradativamente, o caráter místico e religioso. Acreditava ter a missão de "redimir o mundo e restituir seu estado de beatitude"7; para tanto, deveria transformar-se em mulher e povoar o mundo com uma nova raça, o que vem a efetivar, através do delírio de remissão da humanidade, sua fantasia de ser uma mulher. É interessante notar que Schreber e sua mulher não tinham filhos e isto era uma grande desejo do casal. Essa frustração será, de acordo com Freud, desencadeadora de sua psicose.

Schreber acreditava que alguns de seus de órgãos corporais sofreram danos irreversíveis que levariam à morte qualquer outro homem (seu estômago e seu intestino apodreceram, havia engolido a própria laringe etc.), mas um milagre divino (raios divinos) restauravam o que havia sido destruído e enquanto permanecesse homem, seria imortal. Esses fenômenos cessaram e sua "feminilidade" tornou-se proeminente. Acreditava que grande número de "nervos femininos" haviam passado para seu corpo e uma nova raça de homens originarse-ia, através de um processo de fecundação direta com Deus. Só então restituiria a beatitude ao mundo e poderia morrer.

Na lógica de seu delírio, Schreber acreditava que no decurso de purificação "as almas aprendem a língua que é falada pelo próprio Deus", a chamada "língua básica", num alemão rigoroso e rico em eufemismo. ${ }^{8}$

Freud faz notar que a "surpreendente sexualização do estado de beatitude celestial" sugere a possibilidade de que o conceito que Schreber tem do estado de beatitude derive de uma condensação dos principais significados palavra alemã selig: falecimento e sensualmente feliz.

A respeito do delírio de ser transformado em mulher, Freud nos diz que nada mais era do que "a realização do conteúdo desse sonho". Assim, "o delírio sexual de perseguição (Flechsig - assassino de alma) foi, posteriormente, transformado, na mente do paciente, em delírio religioso de grandeza". ${ }^{9}$

Uma outra coisa interessante a salientar é o paralelo que Freud estabelece entre o trabalho de elaboração onírica e o trabalho de formação dos delírios. Estruturalmente, a vivência do delírio é a mesma que realizamos em cada noite em nossos sonhos; porém, há algo que nos aparta do delírio quando despertamos, e o naufrágio e derrocada da psicose decorre da ausência disso. Veremos mais tarde que Freud estabelecerá uma diferença estrutural entre a neurose e a psicose;

7. Idem.

8. Idem, p. 40

9. Idem, p. 34. 


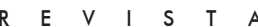

LATINOAMERICANA

DE PSICOPATOLOGIA

F U N D M N T A L

enquanto neuróticos, sonhamos sem nos perdermos no mundo fantástico da psicose. Essa diferença discutiremos mais adiante. Retomemos o caso Schreber.

Em seu delírio, Schreber dividia a alma de Flechsig e Weber em várias. Isto é importante para a compreensão não apenas da Psicose, mas tem um interesse teórico muito maior, no sentido de que o eu é apenas ilusoriamente sintético. $\mathrm{Na}$ verdade, somos vários eus; enquanto neuróticos, lutamos para estabelecer uma unidade ficcional, que no psicótico eclode dividida como nas almas construídas por Schreber. Veremos mais adiante este tema.

Retomando a explicação freudiana para a paranóia, vemos que a pessoa eleita como perseguidor foi, num momento anterior, objeto de admiração e devoção, de um amor homoerótico sublimado. Na psicose, diz Freud,

... a fantasia feminina sai vencedora e só é preciso ligeira correção da imprecisão paranóica característica do modo de expressão de Schreber, para permitir-nos adivinhar o fato de que o paciente temia um abuso das mãos do próprio médico. A causa ativadora de sua doença, então, foi uma manifestação da libido homossexual. O objeto desta libido foi, provavelmente, desde o início, o médico, Flechsig, e suas lutas contra o impulso libidinal produziram o conflito que deu origem ao sintoma. ${ }^{10}$

Vemos que Freud trata conceitualmente a paranóia da mesma maneira que o faz em relação às outras neuroses: a paranóia é uma defesa - como nas neuroses de transferência - contra a pulsão homossexual, cujo mecanismo principal é a projeção. Diz que no decorrer de nossa existência, como um pêndulo, oscilamos entre a paixão homossexual e heterossexual; esse movimento oscilatório é diretamente proporcional aos desapontamentos e frustrações que sofremos e podem nos impulsionar para uma das extremidades. No caso da paranóia, premido por um desejo homossexual não reconhecido, o sujeito lança mão da defesa manifesta aí como projeção. ${ }^{11}$ Além disto, tanto quanto na formação de sintomas neuróticos, o sintoma específico de perseguição na paranóia resulta de uma transferência de afetos - alguém que na mais remota infância fora a pessoa mais importante para o paciente - em direção a uma pessoa atual (no caso Schreber, dirigidos à pessoa do médico Flechsig).

Desta forma, "a essência da fantasia de desejo (tornar-se mulher) tornouse a essência da perseguição" 12 atualizada em seu médico que, para Schreber, vinha a ser um "assassino de almas".

10. Idem, p. 61.

11. Idem.

12. Idem, p. 67. 


\section{ARTIGOS}

Mas, em outro momento da psicose, a figura de Flechsig ("a alma Flechsig") foi substituída por Deus. Isto, que aparentemente é um agravamento do sintoma, é visto por Freud como uma solução para o conflito:

Era impossível para Schreber resignar-se a representar o papel de uma devassa para com seu médico, mas a missão de fornecer ao Próprio Deus as sensações voluptuosas que Este exigia não provocava tal resistência por parte do eu (...) Seu eu encontrava satisfação na megalomania, enquanto sua fantasia feminina de desejo avançava e tornava-se aceitável. ${ }^{13}$

A respeito da duplicidade de Flechsig e Deus, Freud a explica dizendo que aquilo que a histeria condensa a paranóia dissolve:

Um processo de decomposição desse tipo é muito característico da paranóia. A paranóia decompõe, tal como a histeria condensa. Ou antes, a paranóia reduz novamente a seus elementos os produtos das condensações e identificações realizadas no inconsciente. ${ }^{14}$

Aliás, fazendo um parêntese na exposição, na introdução do caso Schreber, Freud faz um contraponto entre a paranóia e as outras neuroses: "A investigação psicanalítica da paranóia seria completamente impossível, se os pacientes não possuíssem a peculiaridade de revelar aquelas coisas que outros neuróticos mantêm escondidas como um segredo". ${ }^{15}$ Ou seja, na paranóia o desejo se explicita no próprio ato da projeção. Ele esta lá, escancarado, apenas não reconhecido como meu ou como pertencendo ao eu.

Retomando a relação Flechsig-Deus, Freud faz uma série de considerações a respeito do pai de Schreber ${ }^{16}$ : médico famoso por seus métodos de educação de jovens através da disciplina do corpo, da educação física. Chama a atenção de Freud que tanto Flechsig como Deus ora eram reverenciados ora eram objetos de imprecações por parte de Schreber:

Estamos perfeitamente familiarizados com a atitude infantil dos meninos para com o pai; esta se compõe de uma mistura de submissão e insubordinação amotinada que encontramos na relação de Schreber com o seu Deus e é o protótipo inequívoco dessa relação fielmente copiada. ${ }^{17}$

13. Idem, pp. 67-68.

14. Idem, p. 69.

15. Idem, p. 23.

16. Lacan em seu seminário "As psicoses" traz um fato pitoresco: o único momento em que Schreber se refere ao pai em suas Memórias, o faz mencionando uma passagem de sua vida: fora consultar o livro de seu pai Daniel Gottlieb Exercícios de ginástica de quarto com o fim de tirar uma dúvida sobre a procriação.

17. S. Freud. "O caso Schreber". Op. cit., p. 72. 
$\begin{array}{lllllll}R & E & V & \text { I } & S & T & A\end{array}$

LATINOAMERICANA

DE PSICOPATOLOGIA

FUN D A M EN T A L

Para Freud, não há dúvida de que o complexo paterno foi determinante na formação dos delírios paranóicos de Schreber. Mas, do ponto de vista da formação de sintomas paranóicos, a paranóia é determinada mais pelo mecanismo mediante o qual os sintomas são formados ou a repressão (Verdrängung) ${ }^{18}$ é ocasionada que propriamente pela natureza de seus complexos. Para Freud, todos os casos por ele (e seguidores) estudados tinham como pano de fundo uma defesa contra o desejo homossexual que se desenvolveu em razão de algum tipo de frustração, e que no caso de Schreber a mesma era atribuída às suas tentativas infrutíferas de ter um filho e continuar a linhagem dos Schreber. Ou seja, não é o desejo homossexual em si o gerador da paranóia, mas diante de uma incapacidade de sublimá-lo socialmente - pela amizade, amor à humanidade em geral ou de reconhecê-lo como tal (homossexualidade) -, tal desejo transforma-se na mola mestra da defesa e conseqüente formação da paranóia.

Freud explica a relação entre a paranóia e o desejo homossexual, evocando as etapas pelas quais passa a criança em sua relação com os pais, cuja fundamentação dá-se em relação à noção de corpo-próprio, ou seja, as formas pelas quais a criança se relaciona com seu próprio corpo:

Pesquisas recentes dirigiram nossa atenção para um estádio do desenvolvimento entre o auto-erotismo e o amor objetal. Este estádio recebeu o nome de narcisismo. O que acontece é o seguinte: chega uma ocasião, no desenvolvimento do indivíduo, em que ele reúne suas pulsões sexuais (que até aqui haviam estado empenhadas em atividades auto-eróticas), a fim de conseguir um objeto amoroso; e começa a tomar a si próprio, seu próprio corpo, como objeto amoroso, sendo apenas subseqüentemente que passa daí para a escolha de alguma outra pessoa que não ele mesmo, como objeto. Essa fase eqüidistante entre o auto-erotismo e o amor objetal pode, talvez, ser indispensável normalmente; mas parece que muitas pessoas demoram-se por tempo inusitadamente longo nesse estado e que muitas de suas características são por elas transportadas para os estádios posteriores de seu desenvolvimento. De importância principal no eu do sujeito assim escolhido como objeto amoroso já podem ser os órgãos genitais. A linha de desenvolvimento, então, conduz à escolha de um objeto externo com órgãos genitais semelhantes - isto é, a uma escolha objetal homossexual - e daí ao heterossexualismo. ${ }^{19}$

Então, a escolha narcísica amorosa - tomar a si próprio como objeto de amor -, pela qual todo humano passa, tem importância capital na paranóia. Mas,

18. Passaremos ao largo da discussão terminológica para a tradução de Verdrängung: recalque e repressão são usualmente empregados na literatura psicanalítica e não nos cabe aqui discutir essa questão que perpassa as querelas entre escolas psicanalíticas.

19. Idem, pp. 82-83. 


\section{ARTIGOS}

se este é um estágio pelo qual todos passamos, o que constitui a diferença de uns se tornarem paranóicos e outros não? A explicação dada por Freud encontrase nos modos pelos quais se dá a repressão. Esta explicação é retomada em seu artigo metapsicológico "A repressão" $(1915)^{20}$, no qual descreve os três momentos da repressão - fixação, repressão propriamente dita e o retorno do reprimido que, na verdade apenas didaticamente pode assim ser descrito, já que a repressão enquanto atividade do eu é dinâmica e enquanto mecanismo vê-se no incessante esforço de manter distante do eu tudo o que foi catalogado como desprazer. A repressão resulta de um conflito entre representações, as quais num sistema são prazerosas e noutro, desprazerosas. A terceira fase - retorno do reprimido - é aquela que interessa a Freud para compreender os sintomas patológicos. Ela revela que a repressão fracassou em seu intento de manter afastada da consciência a representação desejante e implica uma regressão do desenvolvimento libidinal ao ponto de fixação, que, no caso da formação de sintomas paranóicos, dá-se no estádio do narcisismo.

Diz ele que

... o processo da repressão propriamente dita consiste num desligamento da libido em relação às pessoas - e coisas - que foram anteriormente amadas. Acontece silenciosamente; dele não recebemos informações; só podemos inferilo dos acontecimentos subseqüentes. O que se impõe tão ruidosamente à nossa atenção é o processo de restabelecimento, que desfaz o trabalho da repressão e traz de volta novamente a libido para as pessoas que ela havia abandonado. Na paranóia, este processo é efetuado pelo método da projeção. Foi incorreto dizer que a percepção suprimida internamente é projetada para o exterior; $a$ verdade é, pelo contrário, como agora percebemos, que aquilo que foi internamente abolido retorna desde fora. ${ }^{21}$

Este retorno desde fora é fundamental para compreendermos os vários tipos de paranóia, como veremos mais adiante.

Apenas para fechar o parágrafo anterior, Freud nos diz que a paranóia traz, em seu interior, traços de megalomania e que o engrandecimento característico do eu se deve à liberação da libido que passa a se vincular ao próprio eu; isto funda o retorno ao estádio do narcisismo "e podemos asseverar que a extensão do retrocesso do homossexualismo sublimado para o narcisismo constitui medida de quantidade de regressão característica da paranóia". ${ }^{22}$

Finalmente, a respeito da paranóia, suas principais formas fundam-se na contradição da proposição única:

20. S. Freud. "A repressão" (1915). Op. cit.

21. S. Freud. "O caso Schreber". Op. cit., p. 95.

22. Idem, pp. 96-97. 


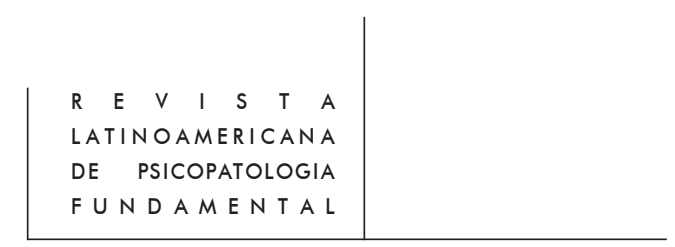

Eu (um homem) o amo (um homem). ${ }^{23}$

a) Delírio de perseguição

Eu não o amo - eu o odeio: ele me odeia, ele me persegue.

b) Erotomania

Eu não o amo - eu a amo: eu noto que ela me ama.

c) Delírios de ciúme

. Alcoólicos: Não sou eu quem ama o homem - ela o ama

A deformação por meio da projeção acha-se necessariamente ausente nesse caso, visto que, com a mudança do sujeito que ama, todo o processo é, de qualquer modo, lançado para fora do eu.

. Delírios de ciúme nas mulheres:

Não sou eu quem ama as mulheres, ele as ama.

Os delírios de perseguição contradizem o predicado, os delírios de ciúme contradizem o sujeito, e a erotomania contradiz o objeto.

d) Megalomania

Não amo de modo algum, não amo ninguém: Eu só amo a mim mesmo.

É uma supervalorização sexual do eu. Freud considera a megalomania uma manifestação hiperbólica da natureza infantil, cujo sacrifício às considerações sociais não foi efetuado como o deveria ter sido num desenvolvimento normal.

Freud considera a paranóia como um tipo clínico independente da parafrenia (termo proposto por ele para substituir demência precoce); a despeito da semelhança que há entre as duas manifestações psicóticas - em ambas, há um desligamento da libido objetal e uma regressão para o eu - a diferença entre ambas se coloca no ponto de fixação disposicional para o retorno do reprimido. Não é demais ressaltar que é no eixo do mecanismo que organiza as neuroses que Freud explica por ora tanto a parafrenia quanto a paranóia: a diferença entre elas reporta ao momento em que se deu a fixação e o retorno da libido a esse ponto. Quanto mais precoce for este retorno, mais grave é a manifestação patológica. $\mathrm{Na}$ parafrenia (ou demência precoce - esquizofrenia)

... a regressão estende-se não simplesmente ao narcisismo (manifestando-se sob a forma de megalomania), mas a um completo abandono do amor objetal e um retorno ao auto-erotismo infantil. A fixação disposicional deve, portanto,

23. Idem, pp. 85-88. 


\section{ARTIGOS}

achar-se situada mais atrás do que na paranóia e residir em algum lugar no início do curso do desenvolvimento entre o auto-erotismo e o amor objetal. Além disto, não é de modo algum provável que impulsos homossexuais, tão freqüentemente - talvez invariavelmente - encontrados na paranóia, desempenhem papel igualmente importante na etiologia dessa enfermidade muito mais abrangente, a demência precoce. ${ }^{24}$

Por tudo isto, o prognóstico da parafrenia é muito mais desfavorável que o da paranóia.

A Freud não escapa que ambas as enfermidades dificilmente se mostram em sua forma pura, sendo mais freqüente que se apresentem combinadas. É assim que o propõe (para o caso Schreber):

... a partir do fato de que, na produção de uma fantasia de desejo e de alucinações, ele apresenta traços parafrênicos, enquanto na causa ativadora, no emprego do mecanismo da projeção e no desfecho exibe um caráter paranóide. ${ }^{25}$

Três anos depois da publicação de sua análise sobre o caso Schreber, Freud publica seu estudo sobre o narcisismo ("Sobre o narcisismo: uma introdução" [1914]). ${ }^{26}$ Nesse artigo, sua pesquisa volta-se às parafrenias (e aí ele inclui a esquizofrenia e paranóia), ao acometimento de alguma doença orgânica (que nos faz afastar do mundo), à hipocondria e à Sua Majestade, o Bebê. Das quatro categorias por ele estudadas, as três primeiras têm em comum a marca de um retorno da libido ao estágio do narcisismo e a última (ao refletir sobre o bebê) temos em germe a constituição do narcisismo; é em relação ao bebê que estabelecerá a noção de um narcisismo primário, que já havia aparecido no texto de Schreber, ao falar do desenvolvimento infantil: "Dizemos que um ser humano tem originalmente dois objetos sexuais - ele próprio e a mulher que cuida dele e ao fazê-lo estamos postulando a existência de um narcisismo primário em todos (...) (p. 104), e de um narcisismo secundário:

O parafrênico parece realmente ter retirado sua libido de pessoas e coisas do mundo externo, sem substituí-las por outras na fantasia (como o faz o histérico). Quando realmente as substitui, o processo parece ser secundário, e constituir parte de uma tentativa de recuperação, destinada a conduzir a libido de volta aos objetos. ${ }^{27}$

24. Idem, p. 102.

25. Idem, p. 103.

26. S. Freud. "Sobre o narcisismo: uma introdução" (1914). Op. cit.

27. Idem, p. 91. 
$\begin{array}{lllllll}R & E & V & \text { I } & S & T & A\end{array}$

LATINOAMERICANA

DE PSICOPATOLOGIA

FUND A M EN T A L

Chama-nos a atenção a palavra realmente, à qual Freud dá ênfase. O psicótico, por lhe ser impossível uma substituição na fantasia (imaginário), estabelece-a no real. Veremos mais tarde, quando tratarmos da questão das palavras e coisas, que o psicótico tomas as palavras como coisas (real). Mas deixemos isto, por ora, em suspenso.

É então no eixo da libido do eu e da libido objetal ( $1^{\text {a }}$ teoria das pulsões) que Freud procura dar explicações às psicoses e neuroses de transferências, respectivamente, mas dando a ambas o mesmo estatuto de defesa.

Devemos trazer agora a distinção que Freud fez entre auto-erotismo e narcisismo. Parece-nos que a noção de narcisismo primário não deve ser confundida com algo originário ao sujeito como o é o auto-erotismo. $\mathrm{O}$ fato de ser primário não significa ser inato ao sujeito no ato do nascimento. Freud nos esclarece dizendo que é necessário uma ação psíquica para que o narcisismo (primário) se estabeleça. E o estabelecimento do narcisismo é simultânea à formação do eu:

... uma unidade comparável ao eu não pode existir no indivíduo desde o começo; o eu tem de ser desenvolvido. Os instintos auto-eróticos, contudo, ali se encontram desde o início, sendo, portanto, necessário que seja adicionado ao auto-erotismo - uma nova ação psíquica - a fim de provocar o narcisismo. ${ }^{28}$

O eu, para além de suas outras funções, forma-se ao dar lugar às primeiras identificações narcísicas e as mesmas se estruturam a princípio de forma incipiente através dessa ação psíquica que é feita de dupla mão: de um lado, os pais (a princípio, em especial, a mãe) ao imantar o bebê com cuidados e amor e, de outro, a própria criança - permeada pelo desejo do pai e da mãe - busca nos pais as primeiras relações identificatórias. Dessa maneira, parece-nos razoável pensar que o que provoca o narcisismo primário e necessário na criança é a reedição do próprio narcisismo dos pais que toma a forma objetal em relação ao bebê. ${ }^{29} \mathrm{Da}$ dispersão anárquica pulsional que se tem no auto-erotismo, passa-se a uma unidade egóica - ficcional, sem dúvida - que é dada pelo narcisismo primário, cujo objeto de amor é o próprio eu do pequeno infante. É o júbilo amoroso em relação a si próprio, como nos diz Lacan, que aí encontramos. Há, então, uma correspondência entre a noção freudiana de narcisismo primário e o estádio do espelho desenvolvido

28. Idem, p. 93.

29. Não nos passa desapercebido que a noção de narcisismo primário não é unívoca no texto freudiano. Como bem notou Laplanche e Pontalis (Vocabulário da psicanálise, pp. 368370) com a introdução conceitual da segunda tópica e da segunda teoria das pulsões, a distinção entre auto-erotismo e narcisismo é esfumaçada; Freud passará a considerar o narcisismo como originário, remetendo-o à vida intra-uterina. 


\section{ARTIGOS}

por Lacan. É na relação com o outro que a criança poderá tomar a si própria como objeto amoroso.

No mesmo artigo sobre o narcisismo - "Sobre o narcisismo: uma introdução" - Freud introduzirá um novo conceito à teoria que advém da noção de narcisismo primário: $\mathrm{O}$ Eu narcísico e onipotente (Eu Ideal) sofre modificações frente à castração. É desta maneira que uma outra instância será formada no psiquismo humano, o Ideal do Eu - protótipo do Superego - que é, ele mesmo, um desdobramento narcísico: "O que ele (o homem) projeta diante de si como sendo seu ideal é o substituto do narcisismo perdido de sua infância na qual ele era seu próprio ideal." ${ }^{30} \mathrm{O}$ ideal do ego, esse outro dentro de nós mesmos, que tanto nos exige, cumpre sua função em todos os nossos desejos, pensamentos e ações. Resultante da triangulação edípica e principalmente dos movimentos da castração, é ele que abre as portas para a mobilidade do desejo.

Não nos surpreenderíamos se encontrássemos um agente psíquico especial que realizasse a tarefa de assegurar a satisfação narcisista proveniente do ideal do ego, e que, com essa finalidade em vista, observasse constantemente o ego real, medindo-o por aquele ideal. Admitindo-se que esse agente de fato exista, de forma alguma seria possível chegar a ele como se fosse uma descoberta podemos tão somente reconhecê-lo, pois podemos supor que aquilo que chamamos de "nossa consciência" possui as características exigidas. O reconhecimento desse agente permite-nos compreender os chamados "delírios" de sermos notados, ou mais precisamente de sermos vigiados, que constituem sintomas tão marcantes nas doenças paranóides, podendo também ocorrer como uma forma isolada de doença, ou intercalados numa neurose de transferência. Pacientes desse tipo queixam-se de que todos os seus pensamentos são conhecidos e suas ações vigiadas e supervisionadas; eles são informados sobre o funcionamento desse agente por vozes que caracteristicamente lhes falam na terceira pessoa ("Agora ela está pensando nisto de novo; agora ele esta saindo"). Essa queixa é justificada; ela descreve a verdade. Um poder dessa espécie, que vigia, que descobre e que critica todas as nossas intenções, existe realmente. $\mathrm{Na}$ realidade, existe em cada um de nós em nossa vida normal.

Os delírios de estar sendo vigiado apresentam esse poder numa forma regressiva, revelando assim sua gênese e a razão porque o paciente fica revoltado contra ele, pois o que induziu o indivíduo a formar um ideal do eu, em nome do qual sua consciência atua como vigia, surgiu da influência crítica de seus pais (transmitida a ele através da voz), ao que vieram juntar-se, à medida que o tempo passou, aqueles que o educaram e lhe ensinaram, a inumerável e indefinível corte de todas as outras pessoas de seu ambiente - seus semelhantes - e a opinião pública. ${ }^{31}$

30. S. Freud. "Sobre o narcisismo: uma introdução". Op. cit., p. 111.

31. Idem, p. 112. 
$\begin{array}{lllllll}R & E & V & \text { I } & S & T & A\end{array}$

LATINOAMERICANA

DE PSICOPATOLOGIA

F U N D M N T A L

Avançamos, então, um pouco mais na compreensão da formação paranóica. Parece-nos que mais importante que a idéia de uma defesa contra a homossexualidade, a questão narcísica atualizada no ideal do eu exerce uma função muito mais intensa. É esse outro em nós mesmos que o paranóico coloca lá fora, que nos parece fundamental na paranóia e, como veremos, nas outras psicoses.

Assim, a paranóia desenvolve-se frente a uma ferida narcísica ou a "uma frustração da satisfação dentro da esfera do ideal do eu"32 que provoca danos irreparáveis ao eu. É a catástrofe vivida pelo paranóico.

Se o ideal do eu (Superego), instância interditora, existe em cada um de nós e abre as portas à mobilidade do desejo, o que, então, determina que no psicótico este ideal esteja lá fora, na figura de um outro que ordena e não internalizado de forma simbólica? Deixemos esta discussão para mais tarde.

Retornando ao caso Schreber: é interessante notar que os delírios da paranóia e as alucinações da parafrenia são vistos por Freud como tentativas de reconstrução. Após a catástrofe o paranóico reconstrói seu mundo através do delírio: "Constrói-o com o trabalho de seu delírio. A formação delirante, que presumimos ser o produto patológico, é, na realidade, uma tentativa de restabelecimento, um processo de reconstrução." 33 Processo semelhante encontramos nas alucinações do esquizofrênico: "Aqui, mais uma vez, podemos considerar a fase de alucinações como uma luta entre a repressão e uma tentativa de restabelecimento, por devolver a libido novamente a seus objetos." ${ }^{34}$

É em 1915 em seu artigo metapsicológico, "O inconsciente", que teremos melhores esclarecimentos sobre o que consiste, pois, a tentativa de reconstrução e restabelecimento. Vimos que Freud nos diz que nas neuroses narcísicas há uma retirada da libido dos objetos e um retorno da mesma em direção ao eu. De certa forma, Freud faz uma retificação dessa observação.

Freud, na última parte deste artigo estabelece relações entre o inconsciente e as formações psicóticas; e é através da observação da fala do esquizofrênico que Freud estabelecerá esta relação. Diz ele:

Nos esquizofrênicos observamos - especialmente nas etapas iniciais, tão instrutivas - grande número de modificações na fala, algumas das quais merecem ser consideradas de um ponto de vista particular. Freqüentemente o paciente devota especial cuidado à sua maneira de se expressar, que se torna "afetada e preciosa". A construção de suas frases passa por uma desorganização peculiar, que as torna incompreensíveis para nós, a ponto de suas observações parecerem disparatadas. ${ }^{35}$

32. Idem, p. 119.

33. S. Freud. "O caso Schreber". Op. cit.

34. Idem, p. 101.

35. S. Freud. "O inconsciente" (1915). Op. cit., p. 225. 


\section{ARTIGOS}

Freud cita o exemplo de uma paciente de Tausk (é notório, pelos exemplos emprestados citados, que Freud não teve, pelas considerações do limite da análise com psicóticos em relação à transferência, experiências clínicas com a psicose) que se queixava depois de uma discussão com o amante, de que "seus olhos não estavam direitos, estavam tortos". A própria paciente dava sua explicação, segundo Tausk:

De forma alguma ela conseguia compreendê-lo, a cada vez ele parecia diferente; era hipócrita, um entortador de olhos (Augenverdreher - sentido figurado de "enganador"), ele tinha entortado os olhos dela, agora via o mundo com olhos diferentes.

Para Freud sua explicação (da paciente de Tausk) tinha valor de uma análise ao mesmo tempo que esclarece a gênese da formação das palavras esquizofrênicas. Sua fala é uma "fala do órgão" com característica hipocondríaca. Freud concorda com Tausk quando ressalta que "a relação da paciente com o órgão corporal (o olho) arrogou-se a si a representação de todo o conteúdo (dos pensamentos dela). ${ }^{37}$

Não nos esqueçamos de que o objetivo de Freud neste artigo é esclarecer a concepção do obscuro inconsciente, utilizando-se das psicoses narcísicas. Dessa maneira, ele aproxima a elaboração onírica das mesmas:

$\mathrm{Na}$ esquizofrenia as palavras estão sujeitas a um processo igual ao que interpreta as imagens oníricas dos pensamentos latentes - que chamamos de processo psíquico primário. Passam por uma condensação e por meio do deslocamento transferem integralmente seus investimentos de uma para outra. O processo pode ir tão longe, que uma única palavra, se for especialmente adequada devido a suas numerosas conexões, assume a representação de todo um encadeamento de pensamento. ${ }^{38}$

No pensar esquizofrênico, como no dos sonhos, a energia segue livre curso de uma representação a outra.

Mas de que forma podemos compreender que as palavras - na psicose não estejam submetidas às leis do processo secundário, fazendo valer as do processo primário? Freud retoma, neste artigo, as idéias desenvolvidas lá na préhistória da psicanálise em seu artigo sobre as afasias (1891). Supõe a existência de uma representação de coisas (Dingvorstellung ou Sachvorstellung) que caracteriza o modo de funcionamento do inconsciente e uma representação de palavras (Wortvorstellung) que quando ligada à representação de coisas permite

36. Idem., p. 226.

37. Idem.

38. Idem, p. 227. 
$\begin{array}{lllllll}R & E & V & \text { I } & S & T & A\end{array}$

LATINOAMERICANA

DE PSICOPATOLOGIA

FUN D A M EN T A L

que tenhamos consciência de nosso pensar. No caso da psicose, há uma regressão a um modo de funcionamento inconsciente, cuja consequiência é tomar as palavras como se fossem coisas.

O que livremente denominamos de representação (Vorstellung) consciente do objeto pode ser agora dividido na representação da palavra e na representação da coisa; a última consiste no investimento, senão nas imagens diretas da memória da coisa, pelo menos de traços de memória mais remotos derivados delas. (...) a representação consciente abrange a representação da coisa mais a representação de palavra que pertence a ela, ao passo que a representação inconsciente é a representação de coisas apenas. O sistema Ics. contém os investimentos da coisa dos objetos, os primeiros e verdadeiros investimentos objetais; o sistema Pcs. ocorre quando essa apresentação da coisa é hiperinvestida (hiperocupada) através da ligação com a apresentação da palavra que lhe corresponde. ${ }^{39}$

Se na esquizofrenia há uma regressão na qual as palavras são tomadas como coisas, podemos pensar, então, que há uma ocupação objetal. É desta maneira que Freud será levado a retificar a concepção na qual nas psicoses narcísicas há um desinvestimento do objeto:

Se agora supusermos essa descoberta ao lado da hipótese de que na esquizofrenia os investimentos objetais são abandonados, seremos obrigados a modificar a hipótese, acrescentando que os investimentos das representações de palavras são retidos. ${ }^{40}$

É bem sabido que nos três artigos citados, há uma tentativa de Freud de continuar a explicar as psicoses pelo mecanismo da repressão. Veremos que mais tarde ele mudará esta concepção, trazendo à luz um outro mecanismo. Mas, nos próprios artigos citados, já percebemos o desconforto encontrado por Freud por não haver um encaixe preciso das peças. No final do artigo sobre $o$ inconsciente ele levanta algumas questões a esse respeito:

... devemos indagar se o processo denominado aqui de repressão tem alguma coisa em comum com a repressão que se verifica nas neuroses de transferência. A fórmula segundo a qual é um processo que ocorre entre os sistemas Ics. e Pcs. (ou Cs.), resultando em manter-se algo à distância da consciência, deve, de qualquer maneira, ser modificada, a fim de também poder incluir o caso da demência precoce e outras afecções narcísicas. ${ }^{41}$

39. Idem, pp. 230-231.

40. Idem, p. 229.

41. Idem, pp. 231-232. 


\section{ARTIGOS}

Parece-nos, como veremos, que a solução encontrada foi o constructo teórico de outro mecanismo que desse conta das psicoses. Além disto, o investimento da representação de palavra não se submete ao ato da repressão, "mas representa a primeira das tentativas de recuperação ou de cura que tão manifestamente dominam o quadro clínico da esquizofrenia." ${ }^{2}$

Mas, se nas neuroses de transferência, por um efeito da repressão, as representações incompatíveis são despojadas de consciência e vem culminar naquilo que Freud denomina fuga do eu, nas neuroses narcísicas, esta fuga é levada às últimas conseqüências: "A mais superficial das reflexões nos revela quão mais radical e profundamente essa tentativa de fuga, essa fuga do eu, é posta em funcionamento nas neuroses narcísicas".

Esta última frase pode parecer contraditória ao que Freud dissera sobre as neuroses narcísicas, em especial no estudo sobre Schreber, no qual nos disse que a libido retorna ao eu e o paranóico toma a si mesmo (seu próprio eu) como objeto amoroso. Como conciliar esta idéia com a que vimos acima, da radical fuga do eu que caracteriza a psicose? Temos que pensar, então, em várias outras frentes: a primeira delas a de que não há unidade do eu, no sentido de um único eu, mas sim, que o eu é, na teoria freudiana, feito um caleidoscópio e isto nos abre a porta para a segunda frente, a da cisão do eu. Podemos entender a fuga do eu nas neuroses narcísicas como a fuga do eu da consciência, ficando em seu lugar um outro eu ou vários outros eus, se assim podemos nos expressar.

No artigo "A perda da realidade na neurose e na psicose" (1924) Freud acaba por concluir que em ambas enfermidades ocorre um processo de perda da realidade, porém, o mecanismo e as conseqüências são radicalmente diferentes. Em ambas há um primeiro momento de "arrastar o eu para longe da realidade", mas a maneira como se dá esse afastamento é diverso nas duas afecções:

Por conseguinte, a diferença inicial assim se expressa no desfecho final: na neurose, o fragmento da realidade é evitado por uma espécie de fuga, ao passo que na psicose ele é remodelado. Ou poderíamos dizer: na psicose, a fuga inicial é sucedida por uma fase ativa de remodelamento; na neurose, a obediência inicial é sucedida por uma tentativa adiada de fuga. Ou ainda, expresso de outro modo: a neurose não repudia a realidade, apenas a ignora; a psicose a repudia (Verleugnung) e tenta substituí-la.

Freud recorre ao exemplo citado em "Estudos sobre a histeria" - Caso Elizabeth - e nos diz que se ela fosse uma psicótica em vez de reprimir

42. Idem, p. 232.

43. Idem.

44. S. Freud. "A perda da realidade na neurose e na psicose” (1924). Op. cit., p. 230.

45. Idem, p. 231. 
$\begin{array}{lllllll}R & E & V & \text { I } & S & T & A\end{array}$

LATINOAMERICANA

DE PSICOPATOLOGIA

FUN D A M EN T A L

(Verdrängen) a pulsão amorosa pelo cunhado, teria rejeitado a morte da irmã. De forma análoga à neurose - aí o reprimido sempre faz suas tentativas de aparecimento, gerando conflito e a formação de sintomas - também nas psicoses o fragmento de realidade rejeitado tenta fazer sua presença: "Provavelmente na psicose o fragmento de realidade rejeitado constantemente se impõe à mente." Porém, a semelhança pára por aí. O fato de a neurose apenas ignorar a realidade, não constitui em si o patológico - a formação de sintomas recai no momento seguinte, cuja fundamentação é o fracasso da repressão. A repressão por si só não basta para constituir o patológico. Na psicose, ao contrário, nos diz Freud, a rejeição da realidade traz em seu cerne o elemento patológico:

A ênfase, porém, é diferente nos dois casos. Na psicose, ela incide inteiramente sobre a primeira etapa, que é patológica em si própria e só pode conduzir à enfermidade. Na neurose, por outro lado, ela recai sobre a segunda etapa, sobre o fracasso da repressão.

Guardemos bem esta passagem, pois ela é fundamental na compreensão da estrutura da psicose. Freud não utiliza um único termo para designar o mecanismo da psicose tal como fizera para explicar as neuroses - a repressão é o mecanismo que dá conta de todas as manifestações neuróticas; acabamos de ver nesse artigo que emprega aí a palavra Verleugnung para designar o mecanismo de repúdio da realidade; em outras passagens, como em "O homem dos lobos" recorre a um outro termo para alcançar o mesmo objetivo: o da rejeição (Verwerfung) da realidade. Esses são os mais empregados por ele. ${ }^{48}$

No artigo "Neurose e psicose" (1923) escrito logo depois da concepção da segunda tópica, Freud volta a discutir a questão de qual mecanismo que, à maneira da repressão, poderia explicar a tal fuga do eu que ocorre nas psicoses. Vemos que não será aqui que descreverá este mecanismo, mas alguns avanços podemos perceber em seu constructo teórico.

As idéias que desenvolve nesse artigo devem ser compreendidas à luz daquilo que resultou da concepção da segunda tópica: que o eu não é senhor em sua própria casa ${ }^{49}$ e que seu martírio consiste em servir senhores diversos e antagônicos. Tais senhores são o Isso (ou Id), o Supereu e o próprio mundo externo que, como veremos, terá importância capital para compreendermos a psicose. Disso resulta que o eu é cindido em várias categorias.

46. Idem, p. 232.

47. Idem, p. 233.

48. Na obra lacaniana, o termo Verwerfung - traduzido por ele por Forclusion - toma uma especificidade e passa a constituir a explicação para a estrutura psicótica.

49. Idéia desenvolvida já em 1917 em seu artigo "Uma dificuldade no caminho da psicanálise" e depois reiterada em "O eu e o isso" (1923). 


\section{ARTIGOS}

É no que diz respeito às relações do eu com o mundo externo que Freud procurará compreender a psicose:

Na amência de Meynert - uma confusão alucinatória aguda que constitui talvez a forma mais extrema e notável de psicose -, o mundo exterior não é percebido de modo algum ou a percepção dele não possui qualquer efeito. Normalmente, o mundo externo governa o eu por duas maneiras: em primeiro lugar, através das percepções atuais e presentes, sempre renováveis; e, em segundo, mediante o armazenamento de lembranças de percepções anteriores, as quais, sob a forma de um "mundo interno", são uma possessão do eu e parte constituinte dele. Na amência não apenas é recusada a aceitação de novas percepções; também o mundo interno, que, como cópia do mundo externo, até agora o representou, perde sua significação (sua ocupação ou investimento). O eu cria, autocraticamente, um novo mundo externo e interno e não pode haver dúvida quanto a dois fatos: (1) que esse novo mundo é construído de acordo com os impulsos desejosos do Isso (ou Id) e (2) que o motivo dessa dissociação do mundo externo é alguma frustração muito séria de um desejo, por parte da realidade - frustração que parece intolerável. A estreita afinidade dessa psicose com os sonhos normais é inequívoca. Uma precondição do sonhar, além do mais, é o estado de sono, e uma das características do sono é o completo afastamento da percepção e do mundo externo.

É a criação de um novo mundo e realidade frente à recusa (repúdio, rejeição) da realidade que, como veremos mais adiante, é a realidade da castração.

E é à luz da segunda tópica que Freud redefinirá os quadros clínicos, tendo em vista as relações do eu com o isso, o superego e o mundo externo:

As neuroses de transferência correspondem a um conflito entre o eu e o isso; as neuroses narcísicas ${ }^{51}$ a um conflito entre o eu e superego e as psicoses, a um conflito entre o eu e o mundo externo. ${ }^{52}$

Vimos no caso Schreber, que diante da frustração de não poder ter um filho que desse continuidade aos Schreber, há o desenvolvimento da fantasia de tornarse mulher (em sonho), o afastamento dessa fantasia projetando-a no mundo externo e, posteriormente, após a catástrofe hipocondríaca, a criação fantástica de um novo mundo. Temos já condições de dar resposta à questão de como conciliar a tese segundo a qual na psicose o eu narcisicamente é tomado como objeto e ao mesmo tempo acontece uma fuga do eu. Devemos compreender esta fuga do eu como um desligamento do eu em relação ao mundo externo - como veremos fuga das interdições que são oferecidas pela castração.

50. S. Freud. "Neurose e psicose" (1924). Op. cit., p. 191.

51. Neste artigo, Freud reservará à categoria neurose narcísica, apenas a melancolia. 52. Idem, p. 192. 
$\begin{array}{lllllll}R & E & V & \text { I } & S & T & A\end{array}$

LATINOAMERICANA

DE PSICOPATOLOGIA

FUN D A M EN T A L

Além disto, o desligamento do eu em relação ao mundo externo e a posterior criação de um novo mundo, fantástico e delirante, é a maneira encontrada para costurar aquilo que foi rasgado na origem:

Com referência à gênese dos delírios, inúmeras análises nos ensinaram que o delírio se encontra aplicado como um remendo no lugar em que originalmente uma fenda apareceu na relação do eu com o mundo externo. ${ }^{53}$

Vimos que Freud fala numa recusa não apenas das percepções internas como das externas e que tal recusa é a tentativa de cerzir o eu rasgado e partido com o mundo externo e anular esse rasgo. Pois bem, sem que ainda a defina como tal, é essa noção de recusa e rejeição que vem a constituir o mecanismo da psicose. Mas antes de seguirmos com a análise desse mecanismo que funda a psicose, vamos nos deter rapidamente na questão da cesura entre o eu e a realidade.

É em um de seus últimos artigos que nos parece o lugar mais adequado para buscar a compreensão desse enigma. Em "A divisão do eu no processo de defesa", Freud dá continuidade à questão do fetiche, de cujo tema não trataremos aqui. Interessa-nos apenas, o que ele desenvolve a respeito da divisão do eu (Ichspaltung). É no interior do conceito de castração que devemos compreender uma divisão desse naipe. Freud supõe uma criança que continuamente pratica a masturbação e, subitamente, se vê ameaçada pela castração: ou ela abandona sua prática e aceita a imposição da realidade ou ela rejeita esta realidade; porém, uma outra via pode acontecer: ela faz as duas coisas ao mesmo tempo.

Por um lado, com o auxílio de certos mecanismos, rejeita a realidade e recusa-se a aceitar qualquer proibição, por outro, no mesmo alento, reconhece o perigo da realidade, assume o medo desse perigo como um sintoma patológico e subseqüentemente tenta desfazer-se do medo. (...) Ambas as partes na disputa obtêm sua cota: permite-se que o instinto (pulsão) conserve sua satisfação e mostra-se um respeito apropriado pela realidade. Mas tudo tem de ser pago de uma maneira ou de outra, e esse sucesso é alcançado ao preço de uma fenda no ego (eu), a qual nunca se cura, mas aumenta à medida que o tempo passa. As duas reações contrárias ao conflito persistem como ponto central de uma divisão do ego (Ichspaltung). Todo esse processo nos parece tão estranho porque tomamos por certa a natureza sintética dos processos do ego. ${ }^{54}$

Temos, então, que inscrever esta cisão do sujeito no âmbito de uma resposta à experiência de castração e que leva a duas posições distintas e contrárias. Em sua obra inacabada "Esboço de psicanálise", Freud retoma ao tema da divisão do eu, cuja proximidade com a questão do fetiche é inegável - o fetichista rechaça a

53. Idem, p. 191.

54. S. Freud. "A divisão do ego no processo de defesa” (1938). Op. cit., p. 310. 


\section{ARTIGOS}

percepção segundo a qual a mulher não tem pênis, e ao mesmo tempo, numa atitude contrária, reconhece que não o possui ${ }^{55}$, mas o que é mais interessante, amplia os efeitos desta constelação conceitual às neuroses, ao homem comum e, por último, mas não menos importante, reitera sua presença nas psicoses.

Como todo conceito psicanalítico, também a esfera da divisão do eu e sua relação com a castração deve ser reconduzida a outros momentos de construção conceitual para não pecarmos por reduzi-lo a um único eixo. Pensando o conceito de Castração, descobrimos que ele não é unívoco e deve ser compreendido no interior de um complexo. O Complexo de Castração, aponta em primeiro lugar, para a diferença anatômica entre os sexos; em segundo lugar para a triangulação edípica; e, em terceiro lugar, como desdobramento das anteriores, a interdição do incesto e no estabelecimento da Lei - e aqui está inserida também a questão da identificação para que a Lei possa ser internalizada. Mas não é apenas isto; Laplanche e Pontalis indicam também que podemos procurar

... situar a angústia de castração numa série de experiências traumatizantes em que intervém igualmente um elemento de perda, de separação de um objeto: perda do seio no ritmo da amamentação, o desmame, a defecação. Tal série encontra a sua confirmação nas equivalências simbólicas, destacadas pela psicanálise, entre os diversos objetos parciais de que o indivíduo é assim separado. Freud, em 1917, consagrava um texto particularmente sugestivo à equivalência pênis $=$ fezes $=$ criança, às metamorfoses do desejo que ela permite, às suas relações com o complexo de castração e com a reivindicação narcísica. $O$ pênis é reconhecido como algo de destacável do corpo. Na mesma linha de investigação, (continua Lapanche) A. Stärke (1921) foi o primeiro a acentuar a experiência da amamentação e da retirada do seio como protótipo da castração: "uma parte do corpo análoga a um pênis é tomada de outra pessoa, é dada à criança como sua (situação a que são associadas sensações de prazer"). Esta castração primária reefetuada de cada vez que lhe retiram o seio para culminar no desmame, seria a única experiência real capaz de traduzir a universalidade do complexo de castração: a retirada do mamilo da mãe seria a significação inconsciente última, sempre encontrada por detrás dos pensamentos, dos temores, dos desejos, que constituem o complexo de castração. ${ }^{56}$

De maneira mais concisa, podemos pensar que o complexo de castração envolve sempre, além do que já foi dito - interdição - uma situação de perda e de separação. Não nos é indiferente que, do ponto de vista freudiano, a castração tenha o seu ponto de angústia culminante na fase fálica. Mas é inegável que a

55. S. Freud. "Esboço de psicanálise" (1938 [1940]). Op. cit., p. 233.

56. J. Laplanche e J.-B. Pontalis. Vocabulário da psicanálise, $8^{\mathrm{a}}$ ed. São Paulo, Martins Fontes, 1985, p. 113. 
$\begin{array}{lllllll}R & E & V & \text { I } & S & T & A\end{array}$

LATINOAMERICANA

DE PSICOPATOLOGIA

FUND A M EN T A L

relação mãe-bebê ocupou um lugar de destaque na teoria freudiana. Desde o princípio em "Projeto para neurólogos" (1995) até o final de seus escritos, esse tema (relação mãe-bebê) percorreu a obra de Freud. Citaremos um trecho de "Esboço de psicanálise" (1938) que ilustrará bem esta questão:

O primeiro objeto erótico de uma criança é o seio da mãe que a alimenta; a origem do amor está ligada à necessidade satisfeita de nutrição. Não há dúvida de que, inicialmente, a criança não distingue entre o seio e o seu próprio corpo; quando o seio tem de ser separado do corpo e deslocado para o exterior, porque a criança tão freqüentemente o encontra ausente, ele carrega consigo, como um "objeto", uma parte dos investimentos libidinais narcísicos originais. Este primeiro objeto é depois completado na pessoa da mãe da criança, que não apenas a alimenta, mas também cuida dela e, assim, desperta-lhe um certo número de outras sensações físicas agradáveis e desagradáveis. Através dos cuidados com o corpo da criança, ela se torna seu primeiro sedutor. Nessas duas relações reside a raiz da importância única, sem paralelo, de uma mãe, estabelecida inalteravelmente para toda a vida como o primeiro e mais forte objeto amoroso e como protótipo de todas as relações amorosas posteriores - para ambos os sexos. ${ }^{57}$

É este estado de fusão originária entre a criança e o seio/mãe, fundamental para a estruturação do psiquismo infantil que nos interessa para compreender o fenômeno psicótico. De forma paradigmática, há também uma indistinção originária entre o eu e o isso (ou id), cuja diferenciação começa a se efetivar diante da urgência da vida:

Podemos imaginar um estado inicial como sendo o estado em que a energia total disponível de Eros, a qual, doravante, mencionaremos como libido, achase presente no ego-id (eu-isso) ainda indiferenciado e serve para neutralizar as tendências destrutivas que estão simultaneamente presentes.

O isso regido pelo puro prazer colocaria em risco a própria sobrevivência do ser; é imperativo, então, que uma outra instância comece a se organizar e a organizar o próprio funcionamento do aparelho psíquico. $\mathrm{O}$ eu, então, se instaura e passa a administrar economicamente as relações representacionais. ${ }^{59}$

Estamos muito próximos da questão da cisão do eu a que se refere Freud para explicar a psicose. Devemos adiantar, contudo, que o fenômeno da divisão do eu não fundamenta por si só a psicose ou outras psicopatologias. Se, por um lado, Freud recorre ao fetiche para dar conta da divisão do eu, por outro, a divisão

57. S. Freud. "Esboço de psicanálise”. Op. cit., pp. 216-217.

58. Idem, p. 175.

59. Ver a este respeio, S. Freud. "Projeto para uma psicologia científica (1950 [1895]). 


\section{ARTIGOS}

do eu (Ichspaltung) é constitutiva do sujeito humano. Não é propriedade privada das psicoses e perversões. ${ }^{60}$ Aliás, tudo leva a crer que a doença se instaura quando o sujeito esfumaça esta cisão, e o delírio como tentativa de cura - a remodelação a que se refere Freud - é, paradoxalmente, a tentativa de restabelecer a divisão do eu; o engodo do psicótico, se assim podemos nos expressar, é não reconhecer que a voz ou as vozes que lhe são imperativas e suas alucinações são criações de seu próprio psiquismo, como quando sonhamos e no ato mesmo do sonhar tomamos as imagens oníricas em sua realidade fantástica com a diferença de que despertamos desse sonho e somos dele arrancados para a realidade da vigília enquanto o psicótico naufraga naquela realidade fantástica.

Dissemos que é paradigmática a fusão bebê seio/mãe com a fusão eu/isso. Vimos que o mecanismo, análogo ao da repressão, que explica as psicoses é o da rejeição (Verwerfung) ou recusa (Verleugnung), e ao fazer isto, Freud abandona o modelo da repressão (Verdrängung) e suas formas de defesa - que, como vimos, advêm da clínica da histeria. A psicose passa a ter uma especificidade que a diferencia das neuroses de transferência. Podemos já reorganizar o que está implicado no mecanismo da rejeição: o psicótico - como o perverso - rejeita a castração que a realidade lhe mostra, rejeita a diferença entre o eu e isso ${ }^{61} \mathrm{e}$, por extensão, podemos pensar numa rejeição da diferença e separação sujeito-criança/ seio-mãe. É chegada a hora de tentarmos harmonizar os vértices daquilo que foi dito para explicar a psicose: vimos que o inconsciente e os sonhos são padrões para a psicose. No inconsciente o que temos são energias livres que se movem formando condensações e deslocamentos, que ocupam tão somente representações de coisa. A imagem plástica dos sonhos aponta para as mesmas relações realizadas por regressão, e as psicoses são, por excelência, aquilo que de mais próximo podemos ter do enigmático inconsciente. Como este, são povoadas por representações de coisa, resultantes de um desligamento da representação de palavra e um retrocesso ou regressão à representação de coisa, forjando a palavra como se fosse uma coisa.

Na vida normal o pensar consciente demanda a ligação da representação de coisa com a representação de palavra, tarefa esta executada pelo eu e que supõe o processo de repressão (do reprimido inconsciente). É condição para a percepção

60. S. Freud. "Esboço de psicanálise". Op. cit., p. 234.

61. É notável o fato de que na psicose o inconsciente torna-se, de forma escancarada, consciente. Também nos sonhos temos essa explosão do inconsciente de forma consciente. Não é por acaso que Freud ao iniciar a parte II de "Esboço de psicanálise" escreve: "Um sonho, então, é uma psicose, com todos os absurdos, delírios e ilusões de uma psicose." No sonho, o homem normal também, como o psicótico, anula a diferença entre o eu e isso, de certa maneira. 
$\begin{array}{lllllll}R & E & V & \text { I } & S & T & A\end{array}$

LATINOAMERICANA

DE PSICOPATOLOGIA

FUND A M EN T A L

consciente e não alucinatória a presença dos signos lingüísticos. Paradoxal e obscuramente, o eu é formado no ato da primeira repressão e, ao mesmo tempo, é ele que instaura o processo de repressão. Então, deste processo resulta a formação do eu e de algo que a ele se opõe, o não-eu. Podemos dizer, que o nãoeu, de um ponto de vista interno, diz respeito ao próprio reprimido inconsciente e suas pulsões de desejo, e de um ponto de vista externo, ao próprio mundo externo, à realidade e ao superego (interdição e identificação), que em última instância, acaba por fazer parte do interno. Se a palavra ou signo lingüístico é condição para a representação consciente, devemos pensar também que ela é coadjuvante na separação entre o eu e o não-eu.

Sabemos, desde os primórdios da Psicanálise, que a palavra, organizadora do psiquismo, vem do outro. É o outro (os pais) que ao nomear a criança a nomeia na $3^{\underline{\underline{a}}}$ pessoa $\left(o\right.$ bebê). Somos, originariamente, ele $e^{62}$ ou isso; só mais tarde seremos designados $t u\left(2^{\underline{a}}\right.$ pessoa) e, de forma contorcionista, poderemos nos atribuir a nós mesmos um $e u{ }^{63}$ Fica, então, mais fácil compreender como o Eu a princípio não se diferencia do isso (ou id) e só mais tarde dele se separa. Mas dessa confusão entre a $1^{\underline{\underline{a}}}$, a $2^{\underline{\underline{a}}}$ e a $3^{\underline{\underline{a}}}$ pessoa parece que não nos livramos jamais. E é na psicose onde isto parece estar mais evidente. Da mesma maneira com que rejeita (verwerfen) a diferença entre o eu e o id (isso), o psicótico parece apagar a diferença entre $e u$ ( $1^{\underline{a}}$ pessoa) e ele ( $3^{\underline{a}}$ pessoa): passa a se denominar, como o faz a criança, na terceira pessoa.

A psicose, então, apaga a diferença que a castração impõe. É notável que essa realidade da castração exija seu lugar e, em decorrência da rejeição ou recusa da mesma, é deflagrado a formação de sintomas psicóticos.

Percorremos os pontos principais da obra freudiana com o intuito de compreender analiticamente a formação da estrutura psicótica. Resta-nos ainda dizer algo sobre o tema a que nos propomos desenvolver - as psicoses. Do ponto de vista teórico, Freud explorou exaustivamente todas as possibilidades com o intuito de explicar a psicose; mas não seria exagero dizer que o campo de Freud em relação às psicoses restringiu-se às suas tentativas - iluminadoras, sem dúvida - de explicação do fenômeno da psicose. Neste sentido, podemos dizer que a clínica freudiana não deu conta da psicose. Freud via com restrições a possibilidade de tratamento psicanalítico para a psicose pela dificuldade, senão impossibilidade, do estabelecimento da transferência. Vimos que a libido, no psicótico, retorna ao

62. Não poderíamos deixar de pensar que "a criança" em alemão é um gênero neutro "das Kind" e que o pronome pessoal que lhe corresponde é "es", a forma usada por Freud na segunda tópica para falar do inconsciente (Das Ich und das Es): é a criança sem diferenciação de gênero.

63. Ver a este respeito, Paul Ricoeur: O si-mesmo como um Outro. Campinas, Papirus. 


\section{ARTIGOS}

eu e isto se torna um entrave para a relação transferencial. Além do fator transferencial, Freud pondera que aquela aliança fictícia entre o eu do paciente e o analista se esboroa na relação psicanalítica com o psicótico. Diz ele:

Se o ego do paciente vai ser um aliado útil em nosso trabalho comum, deve - por mais árdua que tenha sido a pressão das forças hostis - ter conservado uma certa coerência e algum fragmento de compreensão das exigências da realidade. Mas isto não é de se esperar do ego de um psicótico ${ }^{64}$; ele não pode cumprir um pacto desse tipo; na verdade, mal poderá engajar-se. Muito cedo terno-nos-á abandonado, bem como a ajuda que lhes oferecemos, e nos mandado juntar-nos às partes do mundo externo que não querem dizer mais nada para ele. Assim, descobrimos que temos de renunciar à idéia de experimentar nosso plano de cura com os psicóticos renunciar a ele talvez para sempre ou talvez apenas por enquanto, até que tenhamos encontrado um outro plano que se lhes adapte melhor. ${ }^{65}$

Apesar do desalento de Freud em relação ao tratamento psicanalítico com psicóticos, não podemos deixar de registrar que os continuadores da obra freudiana - tanto na vertente francesa quanto na inglesa - souberam aproveitar suas reflexões sobre a psicose e a partir daí tornaram possível uma clínica da psicose. Em outro momento, poderíamos dar continuidade ao tema nos apoiando na psicanálise contemporânea.

El objetivo de este trabajo es acompañar el percurso del pensamiento freudiano en relación a la psicosis. Inicialmente, el concepto de psicosis - en especial, la paranoia - es desarrollado por Freud en el interior de su concepción sobre las neurosis y por lo tanto, en el terreno de la Represión [Verdrängung] para, posteriormente, encontrar su especificidad conceptual en el Repudio [Verwerfung] y en la Desmentida [Verleugnung]. Estes conceptos son tributarios de las especulaciones freudianas sobre el narcicismo y de la elaboración de la llamada "segunda tópica".

El trabajo también discute la dificultad de la clínica freudiana en las psicosis dada la imposibilidad de transferencia.

64. Na verdade, Freud irá reconhecer em seu trabalho "Análise terminável e interminável” que uma aliança desse naipe não se pode esperar do ego de ninguém. Em nenhum outro lugar, talvez, Freud trabalhou tão bem a questão das resistências - do paciente e, principalmente, do analista - à análise; e a resistência é sempre uma função do eu - do paciente e do analista - quanto a este último a resistência parece se exacerbar no atendimento com psicótico.

65. S. Freud. "Esboço de psicanálise". Op. cit., p. 200. 


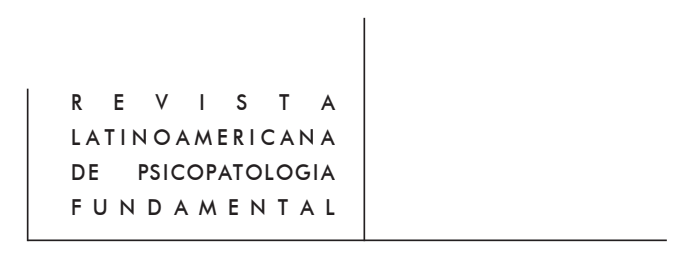

The objective of this article is to follow the path of freudian thought concerning psicosis. The concept of psicosis - particularly, paranoia-was developed by Freud within his conception of neuroses; consequently, in the domain of Repression [Verdrängung] to later find its conceptual specificity with Repudiation

[Verwerfung] and Denial [Verleugnung]. These concepts are tributaries of the freudian speculations regarding narcisism and the so called 'second topic'.

The article also discusses the difficulties in treating psicoses inherent to freudian clinical practice given the impossibility of establishing transferencial ties.

\section{Bibliografia}

Freud, S. "Notas psicanalíticas sobre um relato autobiográfico de um caso de paranóia" (1911). E.S.B., vol. XII. Rio de Janeiro, Imago, 1974.

"Sobre o narcisismo. Uma introdução" (1914). Op. cit., vol. XIV.

"A repressão" (1915). Op. cit., vol. XIV.

"O inconsciente" (1915). Op. cit., vol. XIV.

"A perda da realidade na neurose e na psicose" (1924). Op. cit., vol. XIX. "Neurose e psicose" (1924). Op. cit., vol. XIX.

"A divisão do ego nos processos de defesa" (1938 [1940]). Op. cit., vol. XXIII.

"Esboço de psicanálise" (1938[1940]). Op. cit., vol. XXIII.

LACAN, J. O seminário. Livro 3. As psicoses. Rio de Janeiro, Jorge Zahar, 1985.

Laplanche, J. e Pontalis, J.-B. Vocabulário da psicanálise, $8^{\underline{a}}$ ed. São Paulo, Martins Fontes, 1985.

Masson, Jeffrey Moussaief (ed.). A correspondência completa de Freud/Fliess 1887-1904. Trad. Vera Ribeiro. Rio de Janeiro, Imago, 1986. 